\title{
PERFORMANCE OF PSA AND OF PSA DENSITY IN THE DIAGNOSIS OF PROSTATE CARCINOMA ${ }^{1}$
}

\author{
Antonio Carlos Pereira Martins ${ }^{2}$ \\ Tiago J. Borelli- Bovo ${ }^{3}$ \\ Rodolfo Borges dos Reis ${ }^{4}$ \\ Edson Luiz Paschoalin ${ }^{4}$ \\ Adauto José Cologna ${ }^{5}$ \\ Haylton Jorge Suaid ${ }^{6}$
}

\begin{abstract}
Objective - The aim of the study was to investigate the influence of the prostate volume and PSA density on the performance of total PSA to diagnosis of prostate carcinoma. Methods - We analyzed 217 patients (PSA $0-10 \mathrm{ng} / \mathrm{ml}$ ) submitted to transrectal sextant prostate biopsy. Criteria for biopsy indication was PSA $>2 \mathrm{ng} / \mathrm{ml}$ and/or digital rectal exam suspicious of prostate cancer. Results - Fifty five patients had prostate neoplasia $(25.3 \%)$ and in $8 / 55(25.3 \%)$ the serum PSA was under $4 \mathrm{ng} / \mathrm{ml}$. The sensitivity and specificity of the test were respectively $98.2 \% / 16.6 \%$ at a cut-off point of $2.5 \mathrm{ng} / \mathrm{ml}$ and $85.4 \% / 38.8 \%$ at cut-off of $4 \mathrm{ng} / \mathrm{ml}$. The corresponding values for prostates $>40 \mathrm{ml}$ or $<40 \mathrm{ml}$ were: $96.2 \% / 8.1 \%$ and $100 \% / 27.2 \%$ at the cut-off point of $2.5 \mathrm{ng} / \mathrm{ml}$, and $92.5 \% / 20 \%$ and $78.5 \% / 62.3 \%$ at a cut-off level of $4 \mathrm{ng} / \mathrm{ml}$. For prostates $<40 \mathrm{ml}$ a PSA cut-off point of $4 \mathrm{ng} / \mathrm{ml}$ leads to a misdiagnosis in $21.4 \%$ of the malignant tumors. The median PSAD of benign prostates are different according to prostate volume $(.40 \mathrm{ml}$ or $<40 \mathrm{ml})$. PSAD at cut-off of 0.08 increases the PSA specificity at both PSA cut-off points. Conclusions - Prostate volume affects the sensitivity and specificity of PSA and the median values of PSAD. PSAD of 0.08 increases the PSA specificity specially at a cut-off point of $2.5 \mathrm{ng} / \mathrm{ml}$ in prostates smaller than 40ml. Available from URL: http://www.scielo.br/acb
\end{abstract}

Key Words - Prostate specific antigen, PSA, PSA density, prostate carcinoma

\section{INTRODUCTION}

The initial enthusiasm on the utility of prostate specific antigen (PSA) for the diagnosis of prostate adenocarcinoma was counterbalanced by reports

PSAD cut-off of 0.08 seems to have a better performance than PSA at a cut-off point of $4 \mathrm{ng} / \mathrm{ml}$ alone or in combination with PSAD specially for prostates $<40 \mathrm{ml}$. showing that benign prostate hyperplasia (BPH) could also rise serum levels of this tumor marker ${ }^{1,2}$. Soon afterwards, Stamey et al. ${ }^{3}$ reported that the elevation of serum concentration of PSA promoted by prostate carcinoma was 10 times higher than that of $\mathrm{BPH}^{3}$. Because of the increasing frequency of $\mathrm{BPH}$ and consequent prostate growth from 40 years on, some additional parameters were proposed in association with PSA. One of these parameters is the PSA density (PSAD) that at the cutoff level of 0,15 , for patients with PSA between 4$10 \mathrm{ng} / \mathrm{ml}$, would discriminate most of the cases of carcinoma from $\mathrm{BPH}^{4}$. But, other studies show that PSAD has no value for such discrimination ${ }^{5}$. Others recommend the PSAD at the cut-off level of 0,15 to make a decision on the indication of a $2^{\text {nd }}$ set prostate biopsy when the $1^{\text {st }}$ set gave a negative result ${ }^{6}$.

The aim of our study was to investigate the influence of PSAD and prostate volume on the performance of PSA to the diagnosis of prostate carcinoma in a subset of patients (with serum PSA $£$ $10 \mathrm{ng} / \mathrm{ml}$ ) submitted to prostate biopsy.

1 This research was developed at HCFMRP-USP with financial support of FAEPA

2 Professor of Urology - FMRP-USP

3 Resident of Urology at HCFMRP-USP

4 Post-graduation alumni

5 Assistant Professor of Urology - FMRP-USP

6 Associate Professor of Urology - FMRP-USP 


\section{METHODS}

From January of 1999 to December of 2001, 217 volunteers with total PSA $£ 10 \mathrm{ng} / \mathrm{ml}$ had undergone transrectal ultrasound guided sextant prostate biopsy at HCFMRP-USP. The age range of patients varied from 42 to 90 years (Mean value \pm SD: $65.4 \pm 8.9$ years). Prostate volume was recorded by transrectal ultrasound at the time of biopsy. Criteria of biopsy indication was PSA higher than $2.5 \mathrm{ng} / \mathrm{ml}$ and/ or digital rectal exami- nation (DRE) suspicious of cancer. The cores were fixed in $10 \%$ formalin and thereafter processed for histology under coloration of hematoxilin-eosin. PSA determination was carried out by the DPC-Immuliteä assay.

We investigate the performance of PSA for the total sample and for subgroups of patients with prostates $>40 \mathrm{ml}$ and $<40 \mathrm{ml}$. PSAD was also analyzed to test its ability to enhance PSA performance.

Series characteristics are displayed on Table 1.

Table 1 - Groups of patients according to the diagnosis and PSA range.

\begin{tabular}{lrcc}
\hline PSA Range & N & Carcinoma N (\%) & BPH N (\%) \\
\hline $0-2,4 \mathrm{ng} / \mathrm{ml}$ & 28 & $1(3.6 \%)$ & $27(95.4 \%)$ \\
$2,5-3.9 \mathrm{ng} / \mathrm{ml}$ & 43 & $7(16.3 \%)$ & $36(83.7 \%)$ \\
$4-10 \mathrm{ng} / \mathrm{ml}$ & 146 & $47(32.2 \%)$ & $99(67.8 \%)$ \\
Total & 217 & $55(25.3 \%)$ & $162(74.7 \%)$ \\
\hline
\end{tabular}

Statistical analysis was performed with assistance of a software program. Continuous variables that did not get through the normality test were compared by the Mann-Whitney test. The level of significance was established by double-tailed $p$ value $<0.05$. The influence of PSAD on PSA sensitivity and specificity was studied through the receiver operating characteristic curves (ROC)

\section{RESULTS}

The performance of PSA to the diagnosis of prostate carcinoma at cut-off levels of $2.5 \mathrm{ng} / \mathrm{ml}$ and $4.0 \mathrm{ng} / \mathrm{ml}$ is presented on Table 2 .

Table 2 - Overall PSA performance at two cut-off levels.

\begin{tabular}{cccccccc}
\hline $\begin{array}{c}\text { PSA } \\
\text { cut-off }\end{array}$ & Sensitivity & Specificity & PPV & NPV & $\begin{array}{c}\text { Overall } \\
\text { Accuracy }\end{array}$ & $\begin{array}{c}\text { Biopsy \#/ } \\
\text { Tumor }\end{array}$ & $\begin{array}{c}\text { Tumor \# } \\
\text { missed }\end{array}$ \\
\hline $2.5 \mathrm{ng} / \mathrm{ml}$ & $98.2 \%$ & $16.6 \%$ & $28.5 \%$ & $96.4 \%$ & $37.3 \%$ & 4.2 & $1(1.8 \%)$ \\
$4.0 \mathrm{ng} / \mathrm{ml}$ & $85.4 \%$ & $38.8 \%$ & $32.2 \%$ & $88.7 \%$ & $50.7 \%$ & 3.1 & $8(14.5 \%)$ \\
\hline
\end{tabular}

PPV - Positive Predictive Value; NPV - Negative Predictive Value

The influence of prostate volume on the performance of PSA is showed on Table 3.

Table 3 - Influence of prostate volume on PSA performance.

\begin{tabular}{ccccccccc}
\hline $\begin{array}{c}\text { PSA } \\
\text { cut-off }\end{array}$ & $\mathbf{N}$ & $\begin{array}{c}\text { Sensitivity } \\
\%\end{array}$ & $\begin{array}{c}\text { Specificity } \\
\mathbf{\%}\end{array}$ & $\begin{array}{c}\text { PPV } \\
\mathbf{\%}\end{array}$ & $\begin{array}{c}\text { NPV } \\
\mathbf{\%}\end{array}$ & $\begin{array}{c}\text { Overall \% } \\
\text { Accuracy }\end{array}$ & $\begin{array}{c}\text { Biopsy \#/ } \\
\text { Tumor }\end{array}$ & $\begin{array}{c}\text { \% Tumor } \\
\text { missed }\end{array}$ \\
\hline $\begin{array}{c}2.5 \mathrm{ng} / \mathrm{ml} \\
>40 \mathrm{ml}\end{array}$ & 112 & 96.2 & 8.1 & 24.7 & 83.3 & 20.4 & 3.6 & 3.7 \\
$<40 \mathrm{ml}$ & 105 & 100 & 27.2 & 33.3 & 100 & 46.6 & 3.0 & 0.0 \\
$4.0 \mathrm{ng} / \mathrm{ml}$ & & & & & & & & \\
$>40 \mathrm{ml}$ & 112 & 92.5 & 20.0 & 26.3 & 88.2 & 37.5 & 3.8 & 7.4 \\
$<40 \mathrm{ml}$ & 105 & 78.5 & 62.3 & 43.1 & 88.8 & 66.6 & 2.3 & 21.4 \\
\hline
\end{tabular}

PPV - Positive Predictive Value; NPV - Negative Predictive Value: N - Number of patients 
The analysis of PSAD according to diagnosis and prostate volume is summarized on Table 4.

Table 4 - Comparison of PSAD in subsets of patients according to diagnosis and prostrate volume.

\begin{tabular}{|c|c|c|c|c|c|}
\hline \multirow{2}{*}{$\begin{array}{l}\text { Match } \\
\text { A X B }\end{array}$} & \multirow{2}{*}{$\begin{array}{l}\text { PSA cut-off } \\
\mathrm{ng} / \mathrm{ml}\end{array}$} & \multirow{2}{*}{$\begin{array}{r}\text { Prostate } \\
\text { volume }\end{array}$} & \multicolumn{2}{|c|}{ PSAD Values } & \multirow{2}{*}{$\begin{array}{c}\text { P* } \\
\text { Value }\end{array}$} \\
\hline & & & Median & $\begin{array}{c}\text { Lower/Upper } \\
95 \% \text { CI }\end{array}$ & \\
\hline A - Cancer $(\mathrm{N}=54)$ & 2.5 & all & 0.14 & $0.14 / 0.20$ & 0.01 \\
\hline B - BPH $(N=135)$ & & & 0.11 & $0.13 / 0.17$ & \\
\hline$A$ - Cancer $(N=47)$ & 4.0 & all & 0.16 & $0.14 / 0.19$ & 0.22 \\
\hline $\mathrm{B}-\mathrm{BPH}(\mathrm{N}=99)$ & & & 0.13 & $0.12 / 0.15$ & \\
\hline$A$ - Cancer $(N=26)$ & 2.5 & $>40 \mathrm{ml}$ & 0.10 & $0.09 / 0.12$ & 0.75 \\
\hline $\mathrm{B}-\mathrm{BPH}(\mathrm{N}=79)$ & 2.5 & $>40 \mathrm{ml}$ & 0.10 & $0.10 / 0.12$ & \\
\hline $\mathrm{A}$ - Cancer $(\mathrm{N}=28)$ & 2.5 & $<40 \mathrm{ml}$ & 0.21 & $0.18 / 0.25$ & 0.01 \\
\hline $\mathrm{B}-\mathrm{BPH}(\mathrm{N}=56)$ & 2.5 & $<40 \mathrm{ml}$ & 0.14 & $0.14 / 0.20$ & \\
\hline A - Cancer $(\mathrm{N}=22)$ & 4.0 & $<40 \mathrm{ml}$ & 0.23 & $0.20 / 0.28$ & 0.73 \\
\hline $\mathrm{B}-\mathrm{BPH}(\mathrm{N}=29)$ & 4.0 & $<40 \mathrm{ml}$ & 0.22 & $0.20 / 0.28$ & \\
\hline$A$ - Cancer $(N=25)$ & 4.0 & $>40 \mathrm{ml}$ & 0.10 & $0.09 / 0.13$ & 0.70 \\
\hline $\mathrm{B}-\mathrm{BPH}(\mathrm{N}=70)$ & 4.0 & $>40 \mathrm{ml}$ & 0.10 & $0.10 / 0.13$ & \\
\hline $\mathrm{A}$ - Cancer $(\mathrm{N}=28)$ & 2.5 & $>40 \mathrm{ml}$ & 0.21 & $0.18 / 0.25$ & $<0.0001$ \\
\hline$B$ - Cancer $(N=26)$ & 2.5 & $<40 \mathrm{ml}$ & 0.10 & $0.09 / 0.12$ & \\
\hline A - BPH $(N=56)$ & 2.5 & $>40 \mathrm{ml}$ & 0.14 & $0.14 / 0.20$ & 0.0004 \\
\hline $\mathrm{B}-\mathrm{BPH}(\mathrm{N}=79)$ & 2.5 & $<40 \mathrm{ml}$ & 0.10 & $0.10 / 0.12$ & \\
\hline$A$ - Cancer $(N=22)$ & 4.0 & $>40 \mathrm{ml}$ & 0.23 & $0.20 / 0.28$ & $<0.0001$ \\
\hline $\mathrm{B}$ - Cancer $(\mathrm{N}=25)$ & 4.0 & $<40 \mathrm{ml}$ & 0.10 & $0.09 / 0.13$ & \\
\hline $\mathrm{A}-\mathrm{BPH}(\mathrm{N}=29)$ & 4.0 & $>40 \mathrm{ml}$ & 0.20 & $0.20 / 0.28$ & $<0.0001$ \\
\hline $\mathrm{B}-\mathrm{BPH}(\mathrm{N}=70)$ & 4.0 & $<40 \mathrm{ml}$ & 0.10 & $0.10 / 0.13$ & \\
\hline
\end{tabular}

$\mathrm{N}$ - Number of patients; * - two-tailed $\mathrm{p}$ (Mann-Whitney test)

Table 5 shows those PSAD cut-off levels required to keep PSA sensitivity in the same range and its specificity according to some sample characteristics

Table 5 - Influence of PSAD on PSA specificity.

\begin{tabular}{lcccccc}
\hline $\begin{array}{c}\text { PSA } \\
\text { Cut-off } \\
\text { level }\end{array}$ & $\begin{array}{c}\text { Prostate } \\
\text { Volume } \\
(\mathbf{m l})\end{array}$ & $\begin{array}{c}\text { PSAD } \\
\text { Required }\end{array}$ & $\begin{array}{c}\text { Sensitivity } \\
\text { \% }\end{array}$ & $\begin{array}{c}\text { Specificity } \\
\mathbf{\%}\end{array}$ & $\begin{array}{c}\text { Number } \\
\text { biopsies/ } \\
\text { Tumor }\end{array}$ & $\begin{array}{c}\text { Tumors } \\
\text { Missed } \\
\mathbf{\%}\end{array}$ \\
\hline $4 \mathrm{ng} / \mathrm{ml}$ & All & 0.08 & 85.4 & 46.9 & 3.1 & 14.5 \\
$2.5 \mathrm{ng} / \mathrm{ml}$ & All & 0.06 & 98.2 & 21.6 & 3.3 & 1.8 \\
$2.5 \mathrm{ng} / \mathrm{ml}$ & All & 0.08 & 94.5 & 30.8 & 3.1 & 5.4 \\
$4 \mathrm{ng} / \mathrm{ml}$ & $>40 \mathrm{ml}$ & 0.08 & 92.5 & 46.9 & 3.6 & 7.4 \\
$4 \mathrm{ng} / \mathrm{ml}$ & $<40 \mathrm{ml}$ & 0.11 & 78.5 & 62.3 & 2.3 & 21.4 \\
$2.5 \mathrm{ng} / \mathrm{ml}$ & $>40 \mathrm{ml}$ & 0.08 & 96.2 & 19.7 & 3.6 & 3.7 \\
$2.5 \mathrm{ng} / \mathrm{ml}$ & $<40 \mathrm{ml}$ & 0.08 & 100 & 32.4 & 2.8 & 0.0 \\
\hline
\end{tabular}

as determined through the receiver characteristics operating curve (Figure 1). 


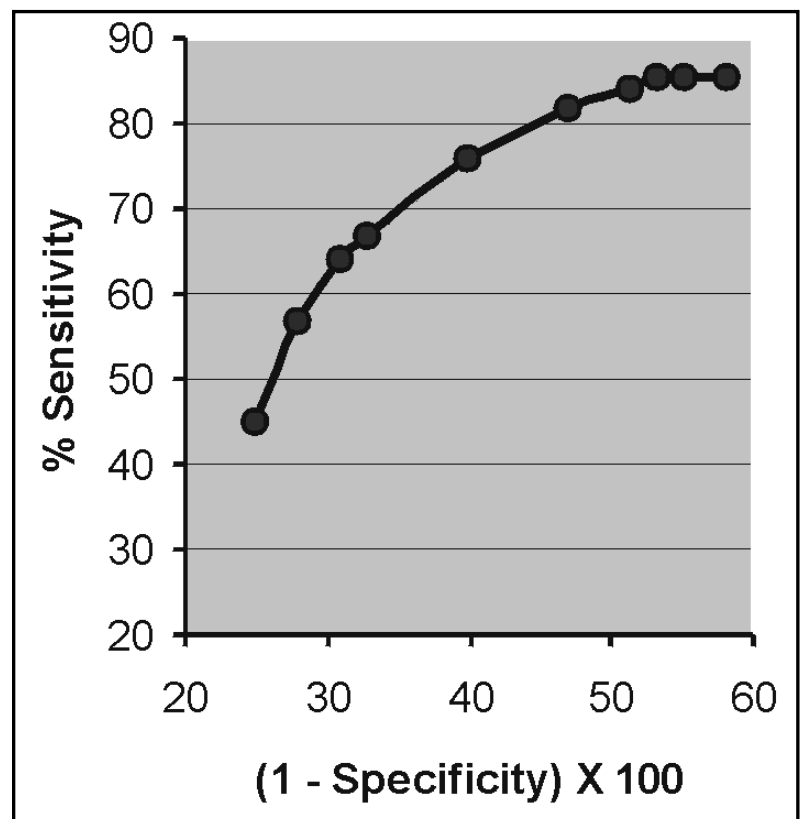

Figure 1 - Receiver characteristics operating curve (ROC) at different cut-off levels of PSAD using PSA at cut-off level of $4 \mathrm{ng} / \mathrm{ml}$ as a reference for all patients.

\section{DISCUSSION}

Our results show in the whole sample that PSA specificity is higher at a cut-off level of $4 \mathrm{ng} / \mathrm{ml}$ than at $2.5 \mathrm{ng} / \mathrm{ml}$. However, this cut-off point is associated with a lower sensitivity leading to misdiagnosis of $14.5 \%$ of neoplasias. On the other hand, PSA specificity is lower at cut-off level of $2.5 \%$ and associated with a higher proportion of unnecessary prostate biopsies.

On Table 3 one can see that the performance of PSA in detection of cancer is influenced by prostate volume. It is worth to mention that $21.4 \%$ of tumors are missed in the subset of patients with prostate volume lower than $40 \mathrm{ml}$ by using PSA cut-off level of $4 \mathrm{ng} / \mathrm{ml}$. The figure for prostates over $40 \mathrm{ml}$ is $7.4 \%$. Catalona et al. ${ }^{7}$ were the first to notice that discrimination between cancer and BPH would require a free-to-total PSA cut-off point of $14 \%$ in prostates $<40 \mathrm{ml}$ and of $23 \%$ in those $>40 \mathrm{ml}$. But, others reported that this ratio is utile in distinction of cancer only in prostates $<60 \mathrm{ml}$ 8 or $<40 \mathrm{ml}^{9,10}$.

The PSA value depends on the cancer volume (and differentiation) as well as the prostate volume ${ }^{3}$. The PSAD parameter was developed to undermine the influence of the prostate volume on the serum level of PSA. However, BPH is heterogeneous and the stroma/ epithelium ratio may vary with the prostate size. Table 4 shows that prostates $<40 \mathrm{ml}$ exhibit higher PSAD values than those $>40 \mathrm{ml}$, which seems in disagreement with the general believe that prostates $>40 \mathrm{ml}$ are of the "glandular" type according to the histology. It is interesting to stress that this phenomenon occurs in prostates with benign or malignant disease. On the other side, median values of PSAD are similar in patients with prostates larger than $40 \mathrm{ml}$ bearing cancer or $\mathrm{BPH}$ independently of the cut-off level of PSA. The median values of PSAD differentiates BPH from prostate carcinoma only for the entire series of patients, or for the subset with prostates smaller than $40 \mathrm{ml}$, at a PSA cut-off level of $2.5 \mathrm{ng} / \mathrm{ml}$ but not at $4 \mathrm{ng} / \mathrm{ml}^{5,6}$.

The analysis of our data through the receiver characteristics operating curve showed that the PSAD at a cut-off level of 0.15 does not enhance PSA sensitivity or specificity. This is in agreement with reports published elsewhere ${ }^{5,6}$. But, a PSA cut-off level of $2.5 \mathrm{ng} / \mathrm{ml}$ associated with a PSAD cut-off point of 0.08 for prostates of all sizes (patients with PSA $£ 10 \mathrm{ng} /$ $\mathrm{ml}$ ) seems a better option for taking the decision on biopsy indication than a PSA cut-off point of $4 \mathrm{ng} / \mathrm{ml}$ alone or in combination with PSAD.

\section{CONCLUSIONS}

Prostate volume affects the sensitivity and specificity of PSA and the median values of PSAD. PSAD of 0.08 increases the PSA specificity specially at a cut-off point of $2.5 \mathrm{ng} / \mathrm{ml}$ in prostates smaller than $40 \mathrm{ml}$.

\section{REFERENCES}

1. Ercole CJ, Lange PH, Mathisen M, Chiou RV, Reddy PK, Vessela RL. Prostate-specific antigen and prostatic acid phosphatase in the monitoring and staging of patients with prostatic cancer. J Urol 1987; 138 : 1181-4.

2. Ferro MA, Barnes I, Roberts JBM, Smith PJB. Tumor markers in prostatic carcinoma: a comparison of prostate-specific antigen with acid phosphatase. Br J Urol 1987; 60: 69-73.

3. Stamey TA, Yang N, Hay AR, McNeal JE, Freiha FS, Redwine E. Prostate-specific antigen as a serum marker for adenocarcinoma of the prostate. N Engl J Med 1987; 317: 909-16.

4. Seaman E, Whang M, Olsson C.A, Katz A, Cooner WH, Benson MC. PSA density (PSAD): role in patient evaluation and management. Urol Clin North Am 1993; 20: 653-63.

5. Akdas A, Tarcan T, Tur Cevik L, Biren T, Ilker Y, Keri L. The impact of prostate-specific antigen density in predicting prostate cancer when serum prostate-specific antigen levels are less than 10ng/ml. Eur Urol 1996; 29: 189-92.

6. Arcangeli CG, Ornstein DK, Keeth DW, Andriole GL. Prostatespecific antigen as a screening test for prostate cancer. The United States experience. Urol Clin North Am 1997; 24: 299306.

7. Catalona WJ, Smith DS, Wolfert RL, Wang TJ, Rittenhouse HG, Ratliff TL, Nadler RB. Evaluation of percentage of free serum PSA improve specificity of prostate cancer screening. J.A.M.A. 1995; 274: 1214-20.

8. Haese A, Graefen M, Noldus J, Hammerer P, Huland E, Huland H. Prostatic volume and ratio of free-to-total prostate specific 
antigen in patients with prostatic cancer or benign prostatic hyperplasia. J Urol 1997; 158: 2188-92.

9. Meyer A, Jung K, Lein M, Rudolph B, Schnorr D, Loening SA. Factors influencing the ratio of free to toal prostate-specifica antigen in serum. Int J Cancer 1997; 74: 630-6.
10. Stephan C, Lein M, Jung K, Lein M, Rudolph B, Schnorr D, Loening SA. The influence of prostate volume on the ratio of free to total prostate specific antigen in serum of patients with prostate carcinoma and benign prostate hyperplasia. Cancer 1997; 79: 104-9.

\section{Address:}

\section{Antonio Carlos Pereira Martins}

Faculdade de Medicina de Ribeirão Preto - USP, Divisão de Urologia

Av. Bandeirantes n ${ }^{\circ}$ 3900, Ribeirão Preto, SP

CEP- 14048-900

e-mail : acpmartins@convex.com.br 